\title{
Pengaruh Inovasi Produk dan Promosi Penjualan terhadap Minat Beli Sepeda Motor Suzuki Satria F150 (Survei pada Komunitas Suzuki Satria F150 Indonesia)
}

\author{
Dede Jajang Suyaman \\ Universitas Singaperbangsa Karawang \\ jajang@fe.Unsika.ac.id
}

\author{
Evi Fitri Andriani \\ Universitas Singaperbangsa Karawang \\ evi.fitri17078@student.unsika.ac.id
}

\section{Sophira Alifiana}

Universitas Singaperbangsa Karawang

sophira.alifiana17212@student.unsika.ac.id

\section{Dewi Juniar \\ Universitas Singaperbangsa Karawang \\ Dewi.juniar17061@student.unsika.ac.id}

\section{Fatimah Azzahra}

Universitas Singaperbangsa Karawang

Fatimah.azzahra17084@student.unsika.ac.id

\begin{abstract}
Abstrak
Teknologi yang saat ini telah berkembang pesat di hampir semua bidang aplikasi bisnis termasuk otomotif telah dimanfaatkan oleh perusahaan dalam mengembangkan sistem teknologi mereka secara sedemikian rupa sehingga mampu memajukan dan mengembangkan usaha dengan sangat baik. Transportasi merupakan komponen utama dalam sistem hidup dan kehidupan, sistem pemerintahan, dan sistem kemasyarakatan. Tujuan penelitian ini adalah untuk mengetahui pengaruh inovasi produk dan promosi penjualana terhadap minat beli sepeda motor Suzuki Satria F150 Indonesia. Jenis penelitian yang digunakan adalah deskriptif dan verifikatif. Populasi dalam penelitian ini adalah anggota yang menggunakan sepeda motor Suzuki Satria F150 Indonesia yang berjumlah 2.463 anggota, dengan sampel sebanyak 96. Teknik sampling penelitian ini adalah Purposive Sampling menggunakan rumus Slovin. Jenis data yang digunakan dalam penelitian ini adalah data primer dan data sekunder. Data diolah menggunakan analisis regresi linier sederhana. Hasil penelitian ini membuktikan bahwa Inovasi Produk dan Promosi Penjualan berpengaruh positif dan signifikan terhadap Minat Beli. Berdasarkan output SPSS pengujian koefisien determinasi secara simultan pada menunjukkan nilai $\mathrm{R}^{2}$ sebesar $41,3 \%$ minat beli (Y) dapat dijelaskan oleh inovasi produk (X1) dan promosi penjualan (X2). Sedangkan sisanya sebesar 58,7\% dijelakan oleh variabel-variabel lain yang tidak diteliti dalam penelitian ini. Sedangkan pengujian koefisien determinasi secara parsial diketahui bahwa variabel inovasi produk
\end{abstract}


memberikan pengaruh terhadap minat beli sebesar $31,3 \%$ sedangkan promosi penjualan memberikan pengaruh terhadap minat beli sebesar $9,9 \%$, nilai tersebut menunjukan nilai $\mathrm{R}^{2}$. Sedangkan sisanya sebesar sebesar 58,8\% dijelakan oleh variabel-variabel lain yang tidak diteliti dalam penelitian ini.

Kata Kunci Inovasi Produk, Promosi Penjualan, Minat Beli

\section{PENDAHULUAN}

Peningkatan jumlah sepeda motor yang pesat telah menimbulkan berbagai persoalan dari segi ekonomi, sosial dan lingkungan. Namun di sisi lain, keberadaan sepeda motor juga menjadi sarana penting bagi masyarakat untuk memperoleh berbagai peluang yang dapat meningkatkan taraf hidupnya, seperti pekerjaan, pendidikan dan kesehatan.

Suzuki Indonesia adalah kelompok usaha yang bergerak di bidang industri otomotif, memproduksi, menjual, dan memperdagangkan sepeda motor, mobil, dan motor temple (outboard-motor). Layanan purna jual yang kokoh dan terintegrasi juga mendukung semua ini, menyediakan suku cadang dan perbaikan atau perawatan kepada pelanggan Suzuki di seluruh Indonesia. (https://www.suzuki.co.id/corporate/tentang-suzuki diakses pada Tanggal 12 Oktober 2019, Pukul 13.27 WIB)

Saat ini di Indonesia sendiri tedapat beberapa merek-merek sepeda motor dengan kualitas top yang ditawarkan oleh perusahaan-perusahaan ternama. Terdapat beberapa nama merek yang hingga saat ini menghiasi segmen pasar otomotif di Indonesia, seperti Honda, Yamaha, Suzuki, Kawasaki, TVS. Dibawah ini merupakan gambaran seperti apa dinamika Penguasaan Market Share Industri Sepeda Motor Indonesia dari 5 anggota AISI ( Honda, Yamaha, Suzuki, kawasaki dan TVS ) yang terjadi diantara kurun waktu tersebut ( lebih dari 8 Tahun - akhir 2009 sampai Mei 2018 ), sebagai berikut:

Share market distribsi Sepeda Motor Indonesia 2009-2018

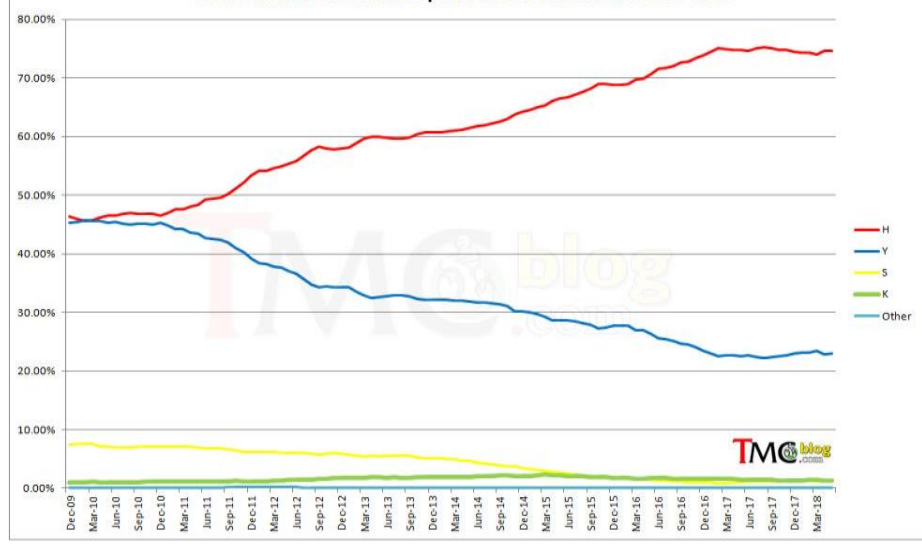

Gambar 1.1

Market Share Sepeda Motor Indonesia 2009-2018

(Sumber: tmcblog.com, diakses pada Tanggal 14 Oktober 2019, Pk 19.15 WIB)

Dari gambar di atas, jika dilihat dari segi minat konsumen, tentunya banyak factor yang mempengaruhi penurunan sepeda motor Suzuki. Dalam penelitian ini berfokus pada salah satu produk sepedah motor andalan Suzuki dalam kategori sepeda motor bebek semi sport yakni Suzuki Satria F150. Suzuki Satria F150 adalah salah satu sepeda motor 
tercepat di kategori underbone 4-Tak. Motor ini diproduksi oleh Suzuki Motor Corporation menggantikan model Suzuki FXR150. (Sumber: https://id.wikipedia.org, diakses pada Tanggal 12 Oktober 2019, Pk 19.05 WIB)

Mesin yang digunakannya telah dilengkapi dengan teknologi injeksi bahan bakar yang menjadikan motor ini lebih irit bahan bakar dibandingkan dengan Suzuki Satria FU generasi sebelumnya yang masih menggunakan sistem pembakaran karburator. Suzuki Satria F150 terbaru dianggap yang tercepat di kelas tulang 150cc. Sepeda motor ini bersaing dengan Sonic 150R milik Honda, yang merupakan saingan terkuatnya. Persaingan mereka sangat ketat dan mereka bersaing untuk mendapatkan produk terlaris di Indonesia. (Sumber: www.otomotifo.com, diakses pada Tanggal 12 Oktober 2019, Pk 21.46 WIB).

Berikut data penjualan sepeda motor Suzuki Satria F150 dari tahun 2016-2018 sebagai berikut:

Tabel 1.1. Data Penjualan Sepeda Motor Suzuki Satria F150 2016-2018

\begin{tabular}{|c|c|}
\hline Tahun & Unit \\
\hline 2016 & 39.465 \\
\hline 2017 & 15.186 \\
\hline 2018 & 9.970 \\
\hline
\end{tabular}

Sumber: (otomotif.tempo.com dan cnnindonesia.com) yang diolah, 2019

Berdasarkan tabel dapat disimpulkan bahwa, penjualan penjualan motor Suzuki Satria F150 mengalami penurunan minat beli konsumen. Menurut Yohan, Penurunan permintaan Satria bukan karena pergeseran kompetitor, melainkan karena pasar mulai beralih ke sepeda motor matik (cnnindonesia.com). Perusahaan harus terus mengembangkan strategi, termasuk strategi pemasaran karena pertumbuhan bisnis yang berkembang dan meningkat, dengan tujuan untuk menarik dan mempertahankan pelanggan (Suhardi \& Irmayanti, 2019). Suzuki Satria F150 sedang mengalami penurunan penjualan, namun bukan berarti Suzuki tianggal diam, mereka terus mendorong nama Satria F250 dengan berbagai cara.

Kunci utama untuk memenangkan persaingan adalah dengan menciptakan inovasi, inovasi harus diciptakan perusahaan karena inovasi adalah salah satu sumber pertumbuhan perusahaan. Inovasi produk merupakan salah satu faktor yang paling diandalkan pemasar saat memasarkan produk. Inovasi akan meningkatkan nilai tambah produk, dan inovasi akan menciptakan produk baru yang dapat memberikan solusi yang lebih baik atas permasalahan yang dihadapi konsumen Rumahak dan Rahayu dalam (Harly \& Octavia, 2017).

Perusahaan yang melakukan inovasi produk juga harus memperhatikan promosi penjualan produknya, karena promosi penjualan juga dapat mempengaruhi untuk memenangkan persaingan. Menurut Agus Hermawan dalam (Sacadikiara \& Tresnati, 2018) Promosi penjualan adalah kegiatan pemasaran yang bertujuan untuk meningkatkan nilai suatu produk dalam jangka waktu tertentu untuk mendorong pembelian konsumen, meningkatkan efisiensi penjualan, atau mendorong upaya tenaga penjualan.

Dilakukannya inovasi produk dan promosi penjualan oleh sepeda motor Suzuki Satria F150, maka akan meningkatkan minat beli konsumen. Minat beli berkaitan dengan rencana konsumen untuk membeli suatu produk tertentu dan berapa banyak unit yang dibutuhkan dalam jangka waktu tertentu (Hasan, 2014). 


\section{LANDASAN TEORI}

\subsection{Inovasi Produk}

Definisi mengenai pengertian inovasi produk menurut Myers dan Marquis dalam (Kotler dan keller, 2016) menyatakan bahwa inovasi produk adalah gabungan dari berbagai macam proses yang saling mempengaruhi antara yang satu dengan yang lain. Jadi Inovasi bukanlah konsep baru, konsep penemuan baru, atau perkembangan pasar baru, tetapi inovasi adalah gambaran dari semua proses ini.

Inovasi produk merupakan salah satu faktor yang paling diandalkan pemasar saat memasarkan produk. Inovasi akan meningkatkan nilai tambah produk, dan inovasi akan menciptakan produk baru yang dapat memberikan solusi yang lebih baik atas permasalahan yang dihadapi konsumen Masda dalam (Dwi Putra \& Ekawati, 2017). Sedangkan menurut (Saladin, 2016) Apa pun yang dapat diberikan ke pasar untuk menarik perhatian, membeli, menggunakan atau mengkonsumsi, dan memenuhi kebutuhan dan keinginan.

Menurut (Kotler \& Keller, 2016) dimensi inovasi produk:

1. Produk baru bagi dunia

2. Lini produk baru

3. Tambahan pada lini produk yang telah ada

4. Perbaikan dan revisi produk yang telah ada

5. Penentuan kembali

6. Pengurangan biaya

\subsection{Promosi Penjualan}

Menurut (Kotler \& Keller, 2016), sales promotion atau promosi penjualan merupakan kunci utama dalam kampanye pemasaran, terdiri dari kumpulan alat intensif, yang sebagian besar bersifat jangka pendek, dirancang untuk merangsang pembelian produk atau layanan tertentu dengan lebih cepat atau lebih oleh konsumen atau pedagang. Promosi merupakan salah satu bentuk persuasi langsung melalui penggunaan berbagai insentif, berbagai insentif dapat disiapkan untuk mendorong pembelian produk secara langsung dan / atau meningkatkan pembelian pelanggan. Salah satu dari lima indikator promosi yang umum adalah promosi, dimana promosi merupakan promosi yang memberikan tindakan langsung kepada konsumen atau calon konsumen untuk segera membeli produk perusahaan(Yoebrilianti, 2018). Sedangkan menurut menurut Agus Hermawan dalam (Sacadikiara \& Tresnati, 2018) promosi adalah kegiatan pemasaran yang mengusulkan nilai tambah produk dalam jangka waktu tertentu untuk mendorong konsumen membeli, meningkatkan efisiensi penjualan atau mendorong tenaga penjualan untuk melakukan upaya.

Penggunaan alat promosi penjualan, menurut (Kotler \& Keller, 2016) yang dialih bahasakan oleh Bob Sabran perusahaan harus menentukan tujuannya, memilih alat, mengembangkan program, menguji program, mengimplementasikan dan mengendalikannya, serta mengevaluasi hasilnya. alat-alat promosi penjualan dapat berupa:

1. Sampel

2. Kupon

3. Penghargaan patronage

4. Diskon

5. Barang gratis

6. Penawaran pengambilan dana tunai (rabat) 
7. Tampilan demonstrasi titik pembelian (P-O-P)

8. Hadiah

9. Paket harga

\section{Minat Beli}

Minat beli merupakan hasil evaluasi konsumen terhadap suatu produk atau jasa, dan evaluasi tersebut berkaitan dengan kualitas, fungsi, dan manfaat yang akan diperoleh saat membeli produk. Ketika konsumen melihat produk dan jasa yang diberikan dari segi tampilan, kemasan dan keunggulan produk, mereka akan tertarik untuk membeli (UtamiSaputra,2017).

Indiator-indikator dari minat beli dijelaskan dalam komponen dari mikro model of consumer responses (Kotler dan Keller dalam Harly \& Octavia, 2017) yaitu :
1. Awareness
2. Knowledge
3. Liking
4. Preference
5. Conviction
6. Purchase

\subsection{Kerangka Pemikiran}

Berdasarkan tinjauan pustaka yang dijabarkan diatas maka peneliti ini menganalisis pengaruh inovasi produk dan promosi penjualan terhadap minat beli. Variabel yang digunakan dalam penelitian ini adalah variabel independen yaitu inovasi produk (X1) dan promosi penjualan (X2) serta variabel dependen yaitu minat beli (Y). Penelitian ini digunakan untuk meneliti pengaruh masing-masing variabel independen terhadap variabel dependen dengan kerangka sebagai berikut:

Inovasi akan meningkatkan nilai tambah suatu produk, inovasi akan menciptakan suatu produk baru yang dapat memberikan solusi yang lebih baik bagi pemecahan masalah yang dihadapi konsumen.

Promosi Penjualan merupakan kunci utama dalam kampanye pemasaran, terdiri dari kumpulan alat insentif, yang sebagian besar bersifat jangka pendek, dirancang untuk merangsang pembelian produk atau layanan tertentu dengan lebih cepat atau lebih oleh konsumen atau perdagangan.

Berdasarkan penjelasan tersebut, maka dapat digambarkan kerangka pemikiran sebagai berikut:

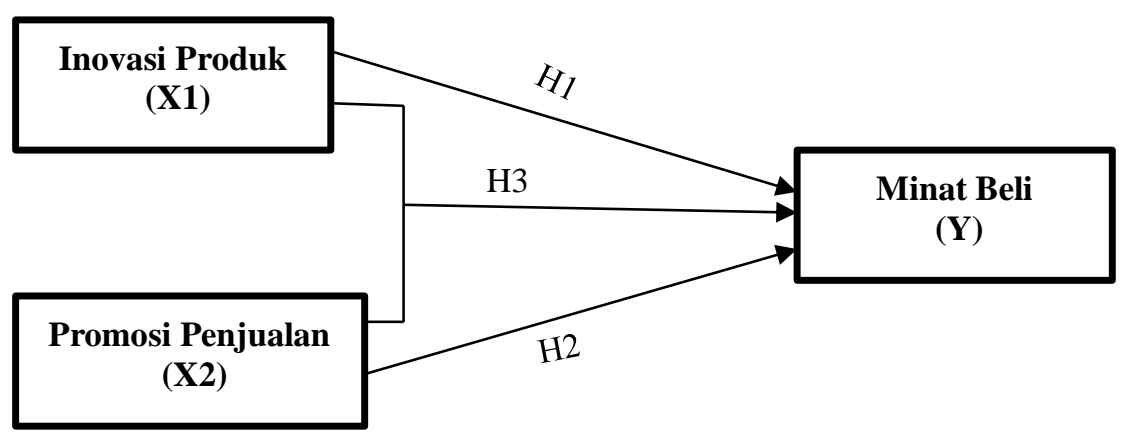

\subsection{Hipotesis}


Hipotesis penelitian dapat diartikan sebagai jawaban yang bersifat sementara terhadap masalah penelitian, sampai terbukti melalui data yang terkumpul dan harus diuji secara empiris. Berdasarkan penjelasan kerangka pemikiran diatas, maka hipotesis penelitian adalah sebagai berikut :

H1 : Terdapat pengaruh secara parsial Inovasi Produk terhadap Minat Beli pada sepeda motor Suzuki Satria F150.

H2 : Terdapat pengaruh secara parsial Promosi Penjualan terhadap Minat Beli pada sepeda motor Suzuki Satria F150.

H3 : Terdapat pengaruh secara simultan Inovasi Produk dan Promosi Penjualan terhadap Minat Beli pada sepeda motor Suzuki Satria F150.

\section{METODOLOGI PENELITIAN}

Dalam penelitian ini, yang menjadi objek penelitian sebagai variabel bebas (independent) adalah inovasi produk (X1) dan promosi penjualan (X2). Adapun objek penelitian yang menjadi variabel terikat (dependent) adalah minat beli (Y). Metode yang dilakukan yaitu metode survey yang termasuk kedalam metode kuantitaf, dimana teknik pengumpulan data yang dilakukan guna memperoleh data dalam penelitian ini adalah sebagai berikut:

1. Studi kepustakaan, yaitu suatu pengumpulan data dengan cara mempelajari buku, makalah, situs website, dan majalah untuk memperoleh informasi yang berhubungan dengan teori dan konsep yang berkaitan dengan masalah dan variabel yang diteliti yang terdiri inovasi produk, promosi penjualan dan minat beli

2. Kuisioner dilakukan dengan menyebarkan seperangkat daftar pernyataan secara online kepada responden. Dalam kuesioner ini penyusun mengemukakan beberapa pertanyaan yang mencerminkan pengukuran indikator variabel X1 (Inovasi Produk), X2 (Promosi Penjualan) serta Variabel Y (Minat Beli).

Jenis penelitian ini menggunakan penelitian deskriptif dan verifikatif. Penelitian deskriptif dilakukan untuk memperoleh gambaran dari inovasi produk, promosi penjualan serta minat beli sepeda motor Suzuki Satria F150 yang dilakukan pada anggota komunitas Suzuki Satria F150 Indonesia. Sedangkan metode verifikatif digunakan untuk mengetahui dan mengkaji besarnya pengaruh inovasi produk dan promosi penjualan terhadap minat beli sepeda motor Suzuki Satria F150 anggota komunitas Suzuki Satria F150.

Populasi dalam penelitian ini adalah seluruh anggota Komunitas Suzuki Satria F150 yang ada di Indonesia. Berdasarkan data Facebook komunitas Suzuki Satria F150 diketahui bahwa jumlah populasi dalam penelitian ini sebanyak 2.463 anggota. Sedangkan teknik yang di ambil dalam pengambilan sampel pada penelitian ini yaitu teknik non-probability sampling dengan jenis purposive sampling. Sampling purposive adalah teknik penentuan sampel dengan pertimbangan tertentu. Peneliti mengambil sampel sebanyak 96 responden dengan menggunakan perhitungan rumus slovin tingkat kesalahan sebesar $10 \%$.

\subsection{Hasil Uji Validitas} berikut:

Keputusan pengujian validitas responden menggunakan taraf signifikansi sebagai

1 Nilai $\mathrm{r}$ dibandingkan dengan $\mathrm{r}$ tabel dengan $\mathrm{dk}=\mathrm{n}-2$ dan taraf signifikansi $\alpha=0,05$

2 Item pertanyaan-pertanyaan responden penelitian dikatakan valid jika rhitung > rtabel. 
3 Item pertanyaan-pertanyaan responden penelitian dikatakan tidak valid jika rhitung lebih kecil dari rhitung < rtabel

Uji validitas untuk mengatahui apakah instrrumen yang digunakan untuk mencari data primer dalam penelitian dapat digunakan untuk mengukur apakah yang harus diukur. Penelitian ini menggunakan uji validitas dari instrumen inovasi produk dimana jumlah pernyataan untuk variabel X1 adalah 9 pernyataan, jumlah pernyataan promosi sebagai variabel X2 adalah 9 pernyataan, dan jumlah pernyataan untuk minat beli sebagai variabel $\mathrm{Y}$ adalah 9 pernyataan.

Tabel 3.1. Hasil Pengujian Validitas Inovasi Produk

\begin{tabular}{|l|c|c|c|}
\hline \multicolumn{1}{|c|}{ Kuisioner } & $\begin{array}{c}\text { Nilai Koefisien Korelasi / r } \\
\text { hitung }\end{array}$ & $\begin{array}{c}\text { Nilai r } \\
\text { kritis / } \\
\text { rtabel }\end{array}$ & Keterangan \\
\hline X1.1 & 0,483 & 0,1654 & Valid \\
\hline X1.2 & 0,741 & 0,1654 & Valid \\
\hline X1.3 & 0,747 & 0,1654 & Valid \\
\hline X1.4 & 0,787 & 0,1654 & Valid \\
\hline XI.5 & 0,650 & 0,1654 & Valid \\
\hline X1.6 & 0,660 & 0,1654 & Valid \\
\hline X1.7 & 0,714 & 0,1654 & Valid \\
\hline X1.8 & 0,682 & 0,1654 & Valid \\
\hline X1.9 & 0,609 & 0,1654 & Valid \\
\hline
\end{tabular}

Sumber : Pengolahan Data, 2019 (IBM SPSS Statistics 16 for windows)

Tabel 3.1 pada instrumen variabel inovasi produk menunjukkan bahwa keseluruhan item pertanyaan dinyatakan valid. Dinyatakan dengan nilai rhitung < rtabel.

Tabel 3.2. Hasil Pengujian Validitas Promosi Penjualan

\begin{tabular}{|c|c|c|c|}
\hline Kuisioner & $\begin{array}{c}\text { Nilai Koefisien } \\
\text { Korelasi / r hitung }\end{array}$ & $\begin{array}{c}\text { Nilai r kritis } \\
\text { / r tabel }\end{array}$ & Keterangan \\
\hline X2.1 & 0,757 & 0,1654 & Valid \\
\hline X2.2 & 0,665 & 0,1654 & Valid \\
\hline X2.3 & 0,769 & 0,1654 & Valid \\
\hline X2.4 & 0,750 & 0,1654 & Valid \\
\hline X2.5 & 0,752 & 0,1654 & Valid \\
\hline X2.6 & 0,715 & 0,1654 & Valid \\
\hline X2.7 & 0,720 & 0,1654 & Valid \\
\hline X2.8 & 0,640 & 0,1654 & Valid \\
\hline X2.9 & 0,700 & 0,1654 & Valid \\
\hline
\end{tabular}

Sumber : Pengolahan Data, 2019 (IBM SPSS Statistics 16 for windows)

Tabel 3.2 pada instrumen variabel promosi penjualan menunjukkan bahwa keseluruhan item pertanyaan dinyatakan valid. Dinyatakan dengan nilai rhitung $<$ rtabel.

Tabel 3.3. Hasil Pengujian Validitas Minat Beli 


\begin{tabular}{|c|c|c|c|}
\hline Kuisioner & $\begin{array}{c}\text { Nilai Koefisien } \\
\text { Korelasi / r hitung }\end{array}$ & $\begin{array}{c}\text { Nilai r kritis } \\
\text { / r tabel }\end{array}$ & Keterangan \\
\hline Y.1 & 0,622 & 0,1654 & Valid \\
\hline Y.2 & 0,671 & 0,1654 & Valid \\
\hline Y.3 & 0,777 & 0,1654 & Valid \\
\hline Y.4 & 0,808 & 0,1654 & Valid \\
\hline Y.5 & 0,773 & 0,1654 & Valid \\
\hline Y.6 & 0,766 & 0,1654 & Valid \\
\hline Y.7 & 0,800 & 0,1654 & Valid \\
\hline Y.8 & 0,832 & 0,1654 & Valid \\
\hline Y.9 & 0,825 & 0,1654 & Valid \\
\hline
\end{tabular}

Sumber : Pengolahan Data, 2019 (IBM SPSS Statistics 16 for windows)

Tabel 3.3 pada instrumen variabel minat beli menunjukkan bahwa keseluruhan item pertanyaan dinyatakan valid. Dinyatakan dengan nilai rhitung $<$ rtabel.

\subsection{Hasil Uji Reabilitas}

Uji reliabilitas dilakukan untuk mendapatkan tingkat ketepatan alat pengumpulan data yang digunakan. Reliabilitas menunjuk pada suatu pengertian bahwa suatu instrumen cukup dapat dipercaya untuk dapat digunakan sebagai alat pengumpul data, karena instrumen tersebut sudah baik. Kriteria uji reliabilitas dengan rumus alpha adalah apabila rhitung > rtabel, maka alat ukur tersebut reliabel dan juga sebaliknya, jika rhitung < rtabel maka alat ukur tidak reliabel.

Tabel 3.4. Hasil Pengujian Reabilitas

\begin{tabular}{|l|l|l|l|l|}
\hline No. & Variabel & r hitung & r tabel & Keterangan \\
\hline 1 & Inovasi Produk & 0,853 & 0,1654 & Reliabel \\
\hline 2 & Promosi Penjualan & 0,882 & 0,1654 & Reliabel \\
\hline 3 & Minat Beli & 0,909 & 0,1654 & Reliabel \\
\hline
\end{tabular}

Sumber : Pengolahan Data 2019 (IBM SPSS Statistics 16 for windows)

Tabel 3.4 menunjukkan bahwa ketiga variabel yang diteliti dalam penelitian ini dinali reliabel yang berarti bahwa alat ukur dalam penelitian ini merupakan alat ukur yang konsisten dan dapat dipercaya.

\section{HASIL DAN PEMBAHASAN PENELITIAN \\ 4.1 Asumsi Klasik \\ 4.1.1 Uji Linieritas}

Pengujian linieritas dimaksudkan untuk mengetahui linieritas hubungan antara variabel respon dan variabel prediktor. Disamping itu dapat digunakan untuk mengetahui taraf signifikansi penyimpangan linieritas hubungan tersebut. Apabila penyimpangan yang ditemukan tidak signifikan maka dapat disimpulkan hubungan antara variabel 
respon dan prediktor linier. Uji linieritas dapat menggunakan scater plot dan uji korelasi dengan hipotesis sebagai berikut:

H0: $\rho=0$ (tidak ada hubungan linier antara $\mathrm{x}$ dan $\mathrm{y}$ )

$\mathrm{H} 1: \rho \neq 0$ (ada hubungan linier antara $\mathrm{x}$ dan $\mathrm{y}$ )

TABEL 4.1

UJI LINIERITAS MODEL REGRESI

Correlations

\begin{tabular}{|ll|r|r|r|}
\hline & & \multicolumn{1}{|c|}{$\mathrm{Y}$} & \multicolumn{1}{c|}{$\mathrm{X} 1$} & \multicolumn{1}{c|}{$\mathrm{X} 2$} \\
\hline Pearson Correlation & $\mathrm{Y}$ & 1.000 & .624 & .508 \\
& $\mathrm{X} 1$ & .624 & 1.000 & .622 \\
& $\mathrm{X} 2$ & .508 & .622 & 1.000 \\
\hline Sig. (1-tailed) & $\mathrm{Y}$ &. & .000 & .000 \\
& $\mathrm{X} 1$ & .000 &. & .000 \\
& $\mathrm{X} 2$ & .000 & .000 & \\
\hline $\mathrm{N}$ & $\mathrm{Y}$ & 100 & 100 & 100 \\
& $\mathrm{X} 1$ & 100 & 100 & 100 \\
& $\mathrm{X} 2$ & 100 & 100 & 100 \\
\hline
\end{tabular}

Sumber : Hasil Pengolahan Data menggunakan Software SPSS Versi 16

Berdasarkan Tabel 4.1 output SPSS, korelasi antara variabel penjelas dan variabel respon, P-value (kolom ketiga) 0,000 < 0.05 . sehingga keputusan tolak $\mathrm{H}_{0}$, artinya variabel penjelas memiliki hubungan linier (korelasi) yang nyata terhadap variabel respon.

\subsubsection{Uji Normalitas}

Normal P.P Plot of Regression Standardized Residual

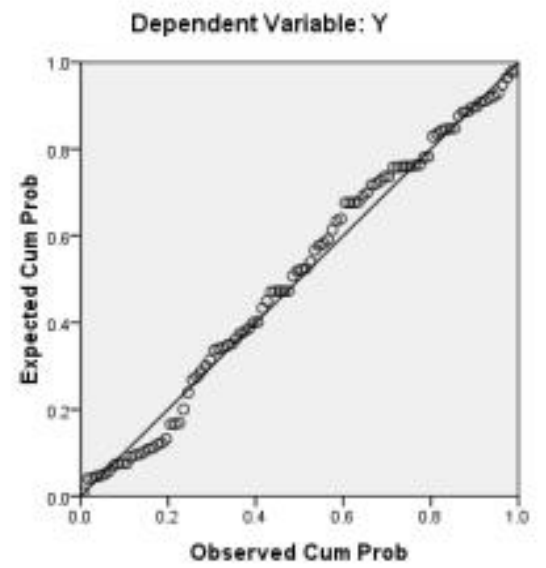

Gambar 4.1

Grafik Normal $\mathbf{P}=\mathbf{P}$ 
Uji normalitas juga dapat dilakukan dengan menggunakan grafik normal P-P Plot yang dapat dilihat pada Gambar 4.1 dimana titik-titik mendekati garis diagonal yang artinya data berdistribusi normal.

Pengujian normalitas data juga dilakukan dengan menggunakan alat uji statistik yaitu uji Kolmogorov Smirnov.

TABEL 4.2. Uji Normalitas Model Regresi

One-Sample Kolmogorov-Smirnov Test

\begin{tabular}{|ll|r|}
\hline & & $\begin{array}{c}\text { Unstandardized } \\
\text { Residual }\end{array}$ \\
\hline N & & 100 \\
& Mean & .0000000 \\
Most Extreme Differences & Std. Deviation & 4.34320533 \\
& Absolute & .078 \\
& Positive & .070 \\
Kolmogorov-Smirnov Z & Negative & -.078 \\
Asymp. Sig. (2-tailed) & & .778 \\
\hline
\end{tabular}

Sumber: Hasil Pengolahan Data, 2019

Tabel 4.2 menunjukkan dengan menggunakan uji kenormalan KolmogorovSmirnov P-value pada uji kenormalan KS sebesar $0.580>0,05$. Sehingga keputusan terima $\mathrm{H} 0$, dapat disimpulkan bahwa residual menyebar normal.

\subsubsection{Uji Heterokedastisitas}

Uji Heteroskedastisitas adalah uji yang menilai apakah ada ketidaksamaan varian dari residual untuk semua pengamatan pada model regresi linear. Metode ini digunakan dengan cara melihat grafik scatter plot antara fitted value dengan residual. Ada tidaknya pola tertentu pada grafik scatter plot dimana sumbu Y adalah nilai Y yang telah diprediksi dan sumbu $\mathrm{X}$ adalah residual ( $\mathrm{Y}$ ).

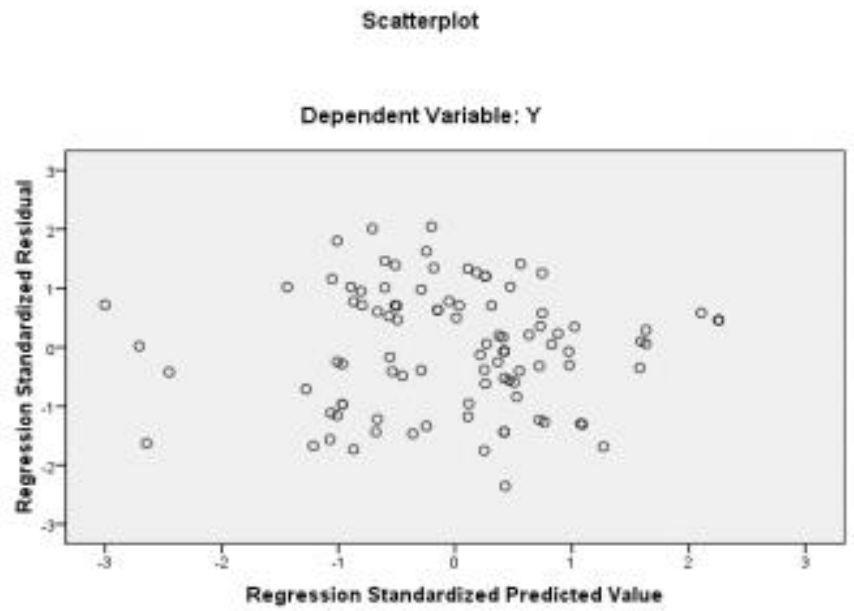




\section{GAMBAR 4.2. UJI HETEROSKEDASTISITAS Sumber: Pengolahan Data, 2019}

Berdasarkan Gambar 4.2 menunjukkan residual menyebar secara acak, tidak mengikuti pola tertentu, sehingga dapat disimpulkan bahwa galat mempunyai ragam yang sama. Dengan demikian, asumsi Homoskedastisitas terpenuhi.

\subsubsection{Uji Multikolinieritas}

Uji multikolinearitas adalah uji yang dilakukan untuk memastikan apakah di dalam sebuah model regresi ada interkorelasi atau kolinearitas antar variabel bebas. Interkorelasi itu dapat dilihat dengan nilai koefisien korelasi antara variabel bebas, nilai VIF dan Tolerance, nilai Eigenvalue dan Condition Index, serta nilai standar error koefisien beta atau koefisien regresi parsial.

Tabel 4.3. Uji Multikolinieritas

\begin{tabular}{|l|l|l|l|}
\hline \multicolumn{2}{|c|}{ Coefficients $^{\mathbf{a}}$} \\
\cline { 3 - 4 } \multicolumn{2}{|c|}{ Model } & \multicolumn{2}{|c|}{ Collinearity Statistics } \\
\cline { 3 - 4 } \multicolumn{2}{|c|}{ Tolerance } & \multicolumn{2}{|c|}{ VIF } \\
\cline { 2 - 4 } & Inovasi Produk & .612 & 1.633 \\
\cline { 2 - 3 } & Promosi Penjualan & .612 & 1.633 \\
\hline
\end{tabular}

Sumber: Hasil Pengolahan Data, 2019

Berdasarkan Tabel 4.3 hasil uji non-multikolonieritas dapat diketahui bahwa nilai VIF dari variabel independen yaitu inovasi produk (X1) dan promosi penjualan (X2) dengan VIF1=1,633 dan VIF2=1,633 menunjukan nilai kurang dari 10. Maka dapat disimpulkan uji asumsi multikolinieritas terpenuhi.

\subsection{Uji Hipotesis}

\subsubsection{Uji Koefisien Determinasi}

TABEL 4.4. Koefisien Determinasi secara Simultan

Model Summary ${ }^{b}$

\begin{tabular}{|c|c|c|c|c|c|c|c|c|c|c|}
\hline \multirow[b]{2}{*}{ Model } & \multirow[b]{2}{*}{$\mathrm{R}$} & \multirow[b]{2}{*}{$\begin{array}{c}\mathrm{R} \\
\text { Square }\end{array}$} & \multirow[b]{2}{*}{$\begin{array}{c}\text { Adjuste } \\
\text { d R } \\
\text { Square }\end{array}$} & \multirow[b]{2}{*}{$\begin{array}{l}\text { Std. } \\
\text { Error of } \\
\text { the } \\
\text { Estimate }\end{array}$} & \multicolumn{5}{|c|}{ Change Statistics } & \multirow[b]{2}{*}{$\begin{array}{l}\text { Durbin- } \\
\text { Watson }\end{array}$} \\
\hline & & & & & $\begin{array}{c}\mathrm{R} \\
\text { Square } \\
\text { Change }\end{array}$ & \begin{tabular}{|c|}
$\mathrm{F}$ \\
Chang \\
$\mathrm{e}$
\end{tabular} & df1 & $\mathrm{df} 2$ & $\begin{array}{c}\text { Sig. F } \\
\text { Change }\end{array}$ & \\
\hline 1 & $\begin{array}{r}.64 \\
3^{\mathrm{a}}\end{array}$ & .413 & .401 & 4.38775 & .413 & 34.132 & 2 & 97 & .000 & 1.305 \\
\hline
\end{tabular}

Sumber: Hasil Pengolahan Data, 2019

Berdasarkan output SPSS pengujian koefisien determinasi secara simultan pada Tabel 4.4 menunjukkan nilai $\mathrm{R}^{2}$ sebesar 0,413 artinya $41,3 \%$ minat beli (Y) dapat dijelaskan oleh inovasi produk (X1) dan promosi penjualan (X2). Sedangkan sisanya sebesar 58,7\% dijelakan oleh variabel-variabel lain yang tidak diteliti dalam penelitian ini.

Tabel 4.5. Koefisien Determinasi Secara Parsial

\section{Coefficients $^{\mathrm{a}}$}




\begin{tabular}{|c|r|r|}
\hline \multirow{2}{*}{ Model } & $\begin{array}{c}\text { Standardized } \\
\text { Coefficients }\end{array}$ & Correlations \\
\cline { 2 - 3 } & Beta & Zero-order \\
\hline (Constant) & & \\
\cline { 2 - 3 } X1 & .503 & .624 \\
\hline X2 & .195 & .508 \\
\hline
\end{tabular}

Sumber: hasil Pengolahan Data, 2019

Berdasarkan Tabel 4.5 pengujian koefisien determinasi secara parsial maka dapat dilakukan perhitungan sebagai berikut:

Pengaruh X1 terhadap $\mathrm{Y}=0,503 \times 0,624=0,313872$ atau $31,3 \%$

Pengaryh X2 terhadap $\mathrm{Y}=0,195 \times 0,508=0,09906$ atau 9,9\%

Berdasarkan perhitungan, diketahui bahwa variabel inovasi produk memberikan pengaruh terhadap minat beli sebesar $31,3 \%$ sedangkan promosi penjualan memberikan pengaruh terhadap minat beli sebesar 9,9\%, nilai tersebut menunjukan nilai $\mathrm{R}^{2}$. Sedangkan sisanya sebesar sebesar 58,8\% dijelakan oleh variabel-variabel lain yang tidak diteliti dalam penelitian ini.

\subsubsection{Pengujian Hipotesis Secara Simultan (Uji F)}

Pengujian dilakukan dengan menggunakan signifiacance level $0,05 \quad(\alpha=5 \%)$. Ketentuan penerimaan atau penolakan hipotesis adalah sebagai berikut:

Jika nilai signifikan > 0,05 maka hipotesis diterima (koefisien regresi tidak signifikan). Ini berarti bahwa secara simultan kedua variabel independen tersebut tidak mempunyai pengaruh yang signifikan terhadap variabel dependen.

Jika nilai signifikan $<0,05$ maka hipotesis ditolak (koefisien regresi signifikan). Ini berarti secara simultan kedua variabel independen tersebut mempunyai pengaruh yang signifikan terhadap variabel dependen.

Uji smultan digunakan unruk mengetahui apakah variabel independen secara bersama-sama atau simultan memengaruhi variabel dependen. Hasil uji $\mathrm{F}$ dalam peneitian dapat diliat pada tabel 4.6 diawah ini:

TABEL 4.6. Uji Simultan

ANOVA $^{\text {b }}$

\begin{tabular}{|ll|r|r|r|r|r|}
\hline Model & & Sum of Squares & Df & Mean Square & F & \multicolumn{1}{c|}{ Sig. } \\
\hline 1 & Regression & 1314.230 & 2 & 657.115 & 34.132 & $.000^{\mathrm{a}}$ \\
& Residual & 1867.480 & 97 & 19.252 & & \\
& Total & 3181.710 & 99 & & & \\
\hline
\end{tabular}

Sumber: Hasil Pengolahan Data, 2019

Berdasarkan tabel 4.6 pengujian hipotesis secara simultan dilakukan dengan uji statistik F, didapatkan nilai signifikan model regresi secara simultan sebesar 0.000 , nilai ini lebih kecil dari significance level $0.05(5 \%)$, yaitu $0,000<0,05$. Selain itu dapat dilihat juga dari hasil perbandingan antara dan $F_{\text {tabel }}$ yang menunjukkan nilai $F_{\text {hitung }}$ sebesar 34,132 sedangkan $F_{\text {tabel }}$ sebesar 2,76. Dari hasil tersebut terlihat bahwa $F_{\text {hitung }}>F_{\text {tabel }}$ yaitu $34,132>2,76$. Sehingga keputusan tolak $\mathrm{H}_{0}$. Artinya, bahwa secara simultan variabel 
independen yaitu inovasi poduk dan promosi penjualan berpengaruh secara signifikan terhadap variabel dependen yaitu minat beli.

\subsubsection{Pengujian Hipotesis Secara Parsial (Uji T)}

Analisis korelasi parsial ini digunakan untuk mengetahui kekuatan hubungan antara korelasi kedua variabel dimana variabel lainnya dianggap berpengaruh dikendalikan atau dibuat tetap (sebagai variabel control). Analisis secara parsial pada penelitian ini dilakukan dengan menggunakan aplikas lisrel 9.30 dan dapat dijelaskan sebagai berikut :

1. Pengaruh $\mathrm{X} 1$ terhadap $\mathrm{Y}$

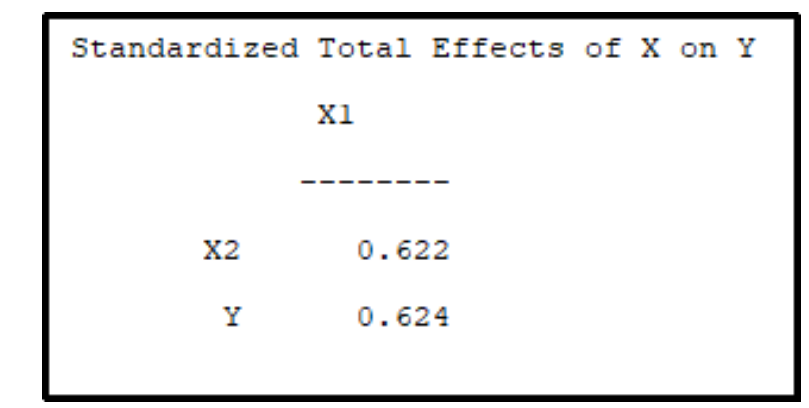

Gambar 4.3. Uji Hipotesis Parsial X1 terhadap Y

Berdasarkan gambar 4.3 hasil output maka dapat diketahui analisis korelasi parsial pada pengaruh total X1 terhadap Y sebesar 0,624.

2. Pengaruh $\mathrm{X} 2$ terhadap $\mathrm{Y}$

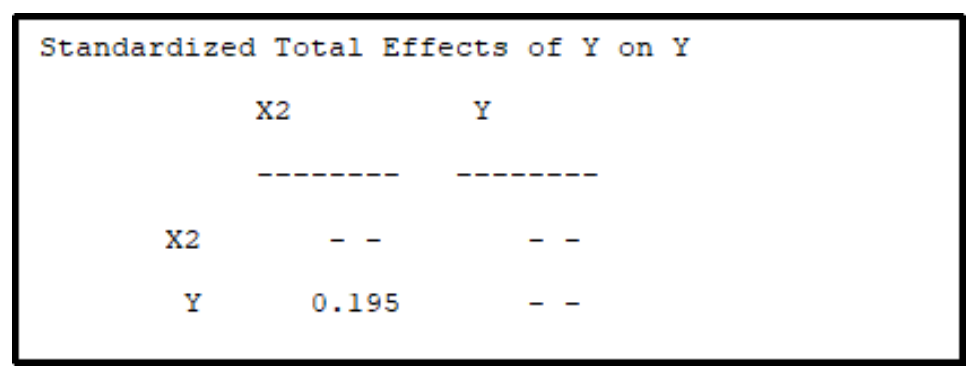

Gambar 4.4. Uji Hipotesis Parsial X1 terhadap Y

Berdasarkan hasil output diatas maka dapat diketahui analisis korelasi parsial pada pengaruh total X2 terhadap Y sebesar 0,195.

\subsection{Pembahasan}

\subsubsection{Gambaran Inovasi Produk}

Berdasarkan hasil skor tersebut diringkas berbagai dimensi yang mempengaruhi pembentukan inovasi produk. Dimensi dengan skor rata-rata tertinggi adalah perbaikan dan revisi produk yang telah ada, sedangkan dimensi dengan skor rata-rata terendah adalah penambahan lini produk yang telah ada. Hasil nilai kontinum inovasi produk termasuk dalam kategori tinggi, artinya dari hasil pengukuran dapat diketahui bahwa diantara variabel inovasi produk yang diteliti dimensi penelitian produk baru, tambahan pada lini produk yang telah ada dan perbaikan dan revisi produk yang telah ada telah berjalan dengan baik dalam penelitian ini. 


\subsubsection{Gambaran Promosi Penjualan}

Berdasarkan hasil rekapitulasi skor dari dimensi-dimensi yang mempengaruhi terbentuknya promosi penjualan. Dimensi yang memperoleh rata-rata skor tertinggi adalah paket harga/ penawaran sedangkan dimensi yang memperoleh rata-rata skor terendah adalah hadiah. Hasil nilai kontinum promosi penjualan termasuk dalam kategori tinggi artinya melalui hasil pengukuran diketahui bahwa dalam variabel promosi penjualan yang diteliti dimensi penelitian hadiah, potongan harga dan paket harga/penawaran telah berjalan dengan baik dalam penelitian ini.

\subsubsection{Gambaran Minat Beli}

Berdasarkan hasil rekapitulasi skor dari dimensi-dimensi yang mempengaruhi terbentuknya minat beli. Dimensi yang memperoleh rata-rata skor tertinggi adalah pembelian sedangkan dimensi yang memperoleh rata-rata skor terendah adalah kesadaran. Hasil nilai kontinum minat beli termasuk dalam kategori tinggi artinya melalui hasil pengukuran diketahui bahwa dalam variabel minat beli yang diteliti dimensi penelitian kesadaran, menyukai dan pembelian telah berjalan dengan baik dalam penelitian ini.

\subsubsection{Pengaruh Inovasi Produk terhadap Minat Beli}

Hasil penelitian ini banyak didukung oleh penelitian-penelitian sebelumnya. Penelitian (Afriyanti \& Ramidani, 2019) yaitu bahwa variabel inovasi produk, kemasan dan variasi produk berpengaruh pada minat beli, namun dari hasil regresi linier berganda menunjukkan bahwa dari kedua variabel tersebut yang sangat paling berpengaruh adalah variabel pemanfaatan variasi produk.

Penelitian (Hans Fanolo Kristian Daeli, 2018) menyatakan bahwa kegiatan inovasi produk berpengaruh terhadap minat beli Smartphone dengan Consumer Innovativeness sebagai variabel moderasi. Sebagaimana terungkap dari penelitian ini, inovasi produk berpengaruh positif terhadap minat beli, semakin tinggi inovasi produk maka akan semakin tinggi pula minat beli dan juga Consumer innovativeness mampu mendorong konsumen untuk mencoba produk baru atau teknologi baru, ingin mempelajari pengetahuan baru yang berimbas pada minat beli.

Hasil penelitian ini bertolak belakang dengan kesimpulan pada jurnal penelitian (Afriyanti \& Ramidani, 2019) yang menyatakan bahwa variabel inovasi produk, kemasan dan variasi produk berpengaruh pada minat beli, dikarenakan inovasi produk berpengaruh negatif dan signifikan terhadap minat beli ice cream Aice di Kota Padang. Dengan signifikansi 0,007 dan t-hitung sebesar -2.279. Hal ini berarti bahwa inovasi produk yang terlalu tinggi akan menurunkan minat konsumen terhadap Aice. Penelitian ini membuktikan dengan hasil nilai kontinum minat beli yang sesuai data penelitian adalah termasuk dalam kategori tinggi artinya bahwa penduduk Indonesia pada kalangan anak muda khususnya anggota Komunitas Suzuki Satria F150 memiliki minat beli yang tinggi. Namun, penelitian ini setuju dengan adanya program inovasi produk dapat meningkatkan volume penjualan karena dengan adanya program inovasi produk dapat mempengaruhi minat beli.

\subsubsection{Pengaruh Promosi Penjualan terhadap Minat Beli}

Hasil penelitian ini banyak didukung oleh penelitian-penelitian sebelumnya. Penelitian (Yoebrilianti, 2018) yaitu bahwa variabel promosi penjualan berpengaruh pada 
minat beli, namun dari hasil regresi linier berganda menunjukkan bahwa dari kedua variabel tersebut yang sangat paling berpengaruh adalah variabel pemanfaatan variasi produk.

Hasil penelitian sejalan dengan logika teori pembahasan sebelumnya. Penelitian (Sacadikiara \& Tresnati, 2018) yang menyebutkan bahwa indikatpr dalam promosi penjualan yang meliputi memberikan sampel menarik untuk mencoba sebuah produk, memberikan kupon yang membangkitkan untuk berbelanja, memberikan harga khusus untuk member yang menarik untuk berbelanja, besarnya potongan harga yang diberikan, periode potongan harga, variasi produk yang didiskon, memberikan harga yang lebih murah, memberikan tanda khusus yang menarik untuk produk yang sedang promo, memberikan produk yang bermanfaat bagi konsumen pada saat event, dan mengadakan kuis untuk memenangkan hadiah yang menarik dapat mendorong untuk melakukan pembelian.

\subsubsection{Pengaruh Inovasi Produk dan Promosi Penjualan terhadap Minat Beli}

Hasil penelitian ini menunjukkan bahwa inovasi produk dan promosi penjualan berpengaruh signifikan secara parsial terhadap minat beli pada Suzuki Satria F150. Berdasarkan hasil pengujian hipotesis tentang pengaruh variabel.

\section{KESIMPULAN}

Berdasarkan hasil penelitian maka dapat disimpulkan bahwa konsumen sepeda motor Suzuki Satria F150 dari kalangan anggota komunitas sepeda motor yang berada di Facebook lebih mengutamakan faktor inovasi produk, sehingga konsumen dengan senang hati tidak akan berpindah ke produk lain. Demikian juga dengan faktor promosi yang menjadi komponen penting dalam menciptakan minat beli di kalangan anggota komunitas dalam menggunakan sepeda motor Suzuki Satria F150. Hal ini juga dibuktikan dengan hasil perhitungan statistik bahwa variabel inovasi produk memberikan pengaruh terhadap minat beli sebesar 31,3\% sedangkan promosi penjualan memberikan pengaruh terhadap minat beli sebesar 9,9\%. Sedangkan sisanya sebesar 58,8\% dijelakan oleh variabelvariabel lain yang tidak diteliti dalam penelitian ini. Adapun pengujian hipotesis secara simultan dilakukan dengan uji statistik F, didapatkan nilai signifikan model regresi secara simultan sebesar 0.000 , nilai ini lebih kecil dari significance level $0.05(5 \%)$, yaitu 0,000 $<0,05$. Selain itu dapat dilihat juga dari hasil perbandingan antara dan $F_{\text {tabel }}$ yang menunjukkan nilai $F_{\text {hitung }}$ sebesar 34,132 sedangkan $F_{\text {tabel }}$ sebesar 2,76. Dari hasil tersebut terlihat bahwa $F_{\text {hitung }}>F_{\text {tabel }}$ yaitu 34,132 > 2,76. Sehingga keputusan tolak $\mathrm{H}_{0}$. Artinya, bahwa secara simultan variabel independen yaitu inovasi poduk dan promosi penjualan berpengaruh secara signifikan terhadap variabel dependen yaitu minat beli.

\section{DAFTAR PUSTAKA}

Dwi Putra, M., \& Ekawati, N. (2017). Pengaruh Inovasi Produk, Harga, Citra Merek Dan Kualitas Pelayanan Terhadap Loyalitas Pelanggan Sepeda Motor Vespa. EJurnal Manajemen Universitas Udayana, 6(3), 1674-1700.

Harly, G. S., \& Octavia, D. (2017). Pengaruh Endorsement Fashion Blogger Terhadap Minat Beli Merek Lokal Pada Tahun 2013 - 2014 (Studi Kasus Pada Fashion Blogger Evita Nuh). Jurnal Manajemen Indonesia, 14(2), 140. 
https://doi.org/10.25124/jmi.v14i2.358

Hasan, A. (2014). Marketing dan Kasus-Kasus Pilihan. Yogyakarta: CAPS.

Kotler dan keller (p. 454). (2016).

Kotler, P., \& Keller, K. L. (2016a). A Framework for Marketing Management. In Marketing Management.

Kotler, P., \& Keller, K. L. (2016b). MarkKotler, P., \& Keller, K. L. (2016). Marketing Management. Global Edition (Vol. 15E).

https://doi.org/10.1080/08911760903022556eting Management. In Global Edition. https://doi.org/10.1080/08911760903022556

Kotler, P., \& Keller, K. L. (2016c). MarkKotler, P., \& Keller, K. L. (2016). Marketing Management. Global Edition (Vol. 15E). In Global Edition. https://doi.org/10.1080/08911760903022556

Sacadikiara, E. H., \& Tresnati, R. (2018). Prosiding Manajemen Pengaruh Promosi Penjualan terhadap Minat Beli Konsumen pada Distro Screamous Bandung The Influence Sales Promotion and Price on Purchase Intentions at Distro Screamous Bandung. (9), 1331-1336.

Saladin (p. 71). (2016).

Suhardi, D., \& Irmayanti, R. (2019). Pengaruh Celebrity Endorser, Citra Merek, dan Kepercayaan Merek Terhadap Minat Beli Konsumen. In Jurnal Inspirasi Bisnis dan Manajemen (Vol. 3). Retrieved from http://jurnal.unswagati.ac.id/index.php/jibm

Utami, R. P., \& Saputra, H. (2017). Pengaruh Harga Dan Kualitas Produk Terhadap Minat Beli Sayuran Organik Di Pasar Sambas Medan. Niagawan, 6(2), 44-53. https://doi.org/10.24114/niaga.v6i2.8334

Yoebrilianti, A. (2018). Pengaruh Promosi Penjualan Terhadap Minat Beli Produk Fashion dengan Gaya Hidup Sebagai Variable Moderator (Survei Konsumen pada Jejaring Sosial). Jurnal Manajemen, 8, 20-41. 